\title{
The Influence of Methyl Jasmonate on Growth and Caffeic Acid Derivative Contents of In vitro Shoot and Roots in Echinaceae (Echinacea Purpurea)
}

\author{
Tunhan Demirci, Serdar Özmen, Elif Gökcen Yılmaz, Özlem Aras Aşcl' Nilgün Göktürk Baydar*
}

Süleyman Demirel University, Faculty of Agriculture, Department of Agricultural Biotechnology Isparta/TURKEY

\begin{abstract}
This study was carried out to determine the effects of methyl jasmonate (MeJA) applications on growth and accumulation of caffeic acid derivatives (CADs) in shoots and roots grown in vitro. For this aim, 28 days old plants obtained from seeds were cultured in $1 / 2$ Murashige and Skoog media containing different concentrations of MeJA $10,10,50$ and $100 \mu \mathrm{M}$ ) and plants were harvested in three times at 15 days intervals. After harvest, growth parameters and CADs in shoot and roots were determined, separately. All growth parameters decreased in line with the elevating level of MeJA applications. But MeJA applications increased the CADs both shoots and roots compared to the controls. The highest cichoric acid, the main CAD of Echinacea, was found in shoots and roots applied with $100 \mu \mathrm{M} \mathrm{MeJA}$ and harvested in 45 days after application.
\end{abstract}

Keywords: Echinacea Purpurea, Methyl Jasmonate, Caffeic Acid Derives, Cichoric Acid

\section{INTRODUCTION}

Echinacea purpurea is an herbaceous perennial species that has gained international popularity because of its nutraceutical and medicinal properties. ${ }^{1}$ Besides alkamides, polysaccharides and glycoproteins, E. purpurea mainly contains caffeic acid derivatives (CADs). ${ }^{2}$ Synthesis of CADs requires expensive, difficult and time-consuming procedures and it is well known that the natural combinations of these compounds are more effective than the artificially obtained compounds. ${ }^{3}$ In vitro techniques combined elicitor treatments may be utilized effectively to improve the secondary metabolites production in plants. Methyl jasmonate (MeJA), a jasmonic acid derivative, is one of the most effective and frequently used elicitor in secondary metabolite production. ${ }^{4}$ MeJA plays a key role in co-ordination of plant defense gene expression. It is a signalling and regulatory molecule influencing enzymes of the biosynthetic pathway responsible for secondary metabolite synthesis. ${ }^{5}$
As the first study on the effects of MeJA in Echinacea, it was aimed to determine the effects of MeJA on growth and production of CADs in in vitro shoots and roots in this study.

\section{MATERIAL AND METHODS}

\section{Plant Materials}

In this study, 28 days old plants obtained from seeds in in vitro conditions were used as plant materials. After washing $70 \%$ ethanol for 30 seconds, seeds were surface-sterilized with $15 \%(\mathrm{v} / \mathrm{v})$ sodium hypochlorite containing $0.1 \%$ Tween 20 for $15 \mathrm{~min}$, then rinsed three times in sterilized water. After sterilization, seeds were cultured on $1 / 2$ MS medium supplemented with $3 \%$ sucrose and $0.6 \%$ agar at $25^{\circ} \mathrm{C}$ with a photoperiod of 16:8 h light: darkness.

\section{Methods}

28 days after sowing, plants were subculture in $1 / 2$ MS medium containing 3\% sucrose, $0.6 \%$ agar and different concentrations of
DOI: 10.5530/ijper.51.3s.77 Correspondence:

Nilgün Göktürk Baydar, Süleyman Demirel University, Faculty of Agriculture, Department of Agricultural Biotechnology Isparta/ TURKEY

Contact: +902462118560

E-Mail: nilgungbaydar@sdu. edu.tr 
MeJA $(0,10,50$ and $100 \mu \mathrm{M})$ and plants cultured at same conditions. Plants were harvested in three times at 15 days intervals. Experiments were performed in triplicate and 12 plants were used for each replication. The harvested plants were divided into shoot and root. Then roots were washed with distilled water to remove the media residues and soaked with tissue paper to remove the surface water. Then shoot and root lengths were determined as $\mathrm{cm}$. The fresh weights of shoots and roots were recorded as g, separately. After dried at $50^{\circ} \mathrm{C}$ to a constant weight, dry weights of shoots and roots were expressed as $\mathrm{mg}$. Extractions and the quantifications of CADs (cichoric acid, caftaric acid, chlorogenic acid, echinacoside, caffeic acid and $o$-coumaric acid) by HPLC were performed by the method of Liu et al. ${ }^{6}$

Data were subjected to analysis of variance with mean separation by Tukey's multiple range test. Differences were considered statistically significant at the $\mathrm{p} \leq 0.05$ levels.

\section{RESULTS AND DISCUSSION}

MeJA applications significantly affected both growth as well as CAD contents of in vitro shoots and roots in Echinacea. All growth parameters including shoot and root lengths and fresh and dry shoot and root weights decreased in line with the elevating level of MeJA (Table 1). The highest values were obtained from the control plants while MeJA especially in high concentrations caused a decline in all growth parameters. These results supported the knowledge that exogenous MeJA applications in in vitro conditions adversely affect the growth of cultures in different plants. ${ }^{78}$ However, an increase in harvest time led to rise in all parameters. The highest values were obtained from the shoots and roots after 45 days.

Application of MeJA to in vitro plants resulted in substantial increases in the production of CADs. All MeJA applications significantly increased the amounts of CADs compared to the control (Table 2). The highest contents of cichoric acid, the most abundant CAD of Echinacea, were obtained from the shoots and roots treated with $100 \mu \mathrm{M}$ MeJA and harvested at 45 day as $35.51 \mathrm{mg} / \mathrm{g}$ and $54.87 \mathrm{mg} / \mathrm{g}$, respectively. Caftaric acid contents were also changed depending on the MeJA applications. The maximum caftaric acid contents were found in shoots and roots applicated with $100 \mu \mathrm{M}$ MeJA after 45 days as in cichoric acid contents. $50 \mu \mathrm{M}$ MeJA and harvest on $45^{\text {th }}$ day combination was found as an optimum application to get maximum chlorogenic acid both shoots and roots. The highest amount of echinacoside in shoots was obtained with $50 \mu \mathrm{M}$ MeJA after 30 days as $0.25 \mathrm{mg} / \mathrm{g}$ while $100 \mu \mathrm{M}$ MeJA and $45^{\text {th }}$ day were found as an optimum MeJA concentration and harvest time for roots. Caffeic acid and o-coumaric acid are intermediates in the biosynthesis steps of CADs such as cichoric acid, chlorogenic acid and caftaric acid. ${ }^{?}$ Application of MeJA depending on its concentration resulted the increase of caffeic acid and o-coumaric acid contents while not being synthesized in control

\begin{tabular}{|c|c|c|c|c|c|c|c|c|c|c|c|}
\hline & \multirow{2}{*}{$\begin{array}{c}\text { MeJA } \\
(\mu \mathrm{M})\end{array}$} & \multicolumn{3}{|c|}{ Harvest time } & \multirow[b]{2}{*}{ Mean } & & \multirow{2}{*}{$\begin{array}{c}\text { MeJA } \\
(\mu \mathrm{M})\end{array}$} & \multicolumn{3}{|c|}{ Harvest time } & \multirow[b]{2}{*}{ Mean } \\
\hline & & Day 15 & Day 30 & Day 45 & & & & Day 15 & Day 30 & Day 45 & \\
\hline \multirow{5}{*}{ 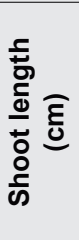 } & 0 & $8.59 \mathrm{Ba}^{*}$ & 10.61 Aa & $10.85 \mathrm{Aa}$ & 10.02 & \multirow{5}{*}{ 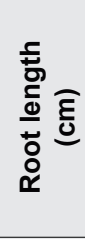 } & 0 & $5.35 \mathrm{Ba}$ & 7.35 Aa & $7.85 \mathrm{Aa}$ & 6.85 \\
\hline & 10 & $4.90 \mathrm{Cb}$ & 7.72 Bb & 8.77 Ab & 7.13 & & 10 & $3.54 \mathrm{Cb}$ & $5.88 \mathrm{Ab}$ & $5.25 \mathrm{Bb}$ & 4.89 \\
\hline & 50 & $3.78 \mathrm{Bc}$ & $6.06 \mathrm{Ac}$ & $6.14 \mathrm{Ac}$ & 5.33 & & 50 & $3.20 \mathrm{Cb}$ & $4.28 \mathrm{Bc}$ & $5.23 \mathrm{Ab}$ & 4.24 \\
\hline & 100 & $3.37 \mathrm{Bc}$ & $4.17 \mathrm{Ad}$ & $4.30 \mathrm{Ad}$ & 3.95 & & 100 & $3.39 \mathrm{Bb}$ & 3.89 ABC & $4.08 \mathrm{Ac}$ & 3.79 \\
\hline & Mean & 5.16 & 7.14 & 7.52 & & & Mean & 3.87 & 5.35 & 5.60 & \\
\hline \multirow{5}{*}{ 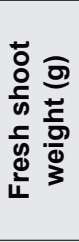 } & 0 & 0.37 & 0.69 & 0.74 & $0.60 a$ & \multirow{5}{*}{ 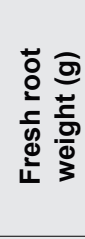 } & 0 & $0.23 \mathrm{Ba}$ & $0.71 \mathrm{Aa}$ & $0.73 \mathrm{Aa}$ & 0.56 \\
\hline & 10 & 0.20 & 0.40 & 0.48 & $0.36 \mathrm{~b}$ & & 10 & $0.16 \mathrm{Bb}$ & $0.58 \mathrm{Ab}$ & $0.55 \mathrm{Ab}$ & 0.52 \\
\hline & 50 & 0.19 & 0.40 & 0.39 & $0.32 \mathrm{~b}$ & & 50 & $0.14 \mathrm{Bb}$ & $0.39 \mathrm{Ac}$ & $0.42 \mathrm{Ad}$ & 0.32 \\
\hline & 100 & 0.18 & 0.27 & 0.27 & $0.39 \mathrm{~b}$ & & 100 & $0.09 \mathrm{Cb}$ & $0.33 \mathrm{Bd}$ & $0.49 \mathrm{Ac}$ & 0.30 \\
\hline & Mean & $0.24 \mathrm{~B}$ & $0.44 \mathrm{~A}$ & $0.47 \mathrm{~A}$ & & & Mean & 0.15 & 0.50 & 0.55 & \\
\hline \multirow{5}{*}{ 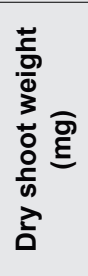 } & 0 & $41.95 \mathrm{Ba}$ & 67.75ABa & $156.85 \mathrm{Aa}$ & 88.85 & \multirow{5}{*}{ 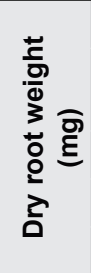 } & 0 & 26.66 & 77.70 & 90.79 & $65.05 a$ \\
\hline & 10 & 37.34 Cab & $55.18 \mathrm{Ba}$ & 85.37Aab & 59.30 & & 10 & 20.64 & 73.40 & 75.65 & $\begin{array}{c}56.56 \\
a b\end{array}$ \\
\hline & 50 & 33.61 Cab & $51.74 \mathrm{Ba}$ & $73.99 \mathrm{Ab}$ & 53.11 & & 50 & 18.23 & 57.92 & 75.27 & $50.48 \mathrm{~b}$ \\
\hline & 100 & $30.81 \mathrm{Ab}$ & $49.49 \mathrm{Aa}$ & $54.93 \mathrm{Ab}$ & 45.07 & & 100 & 13.64 & 54.59 & 75.62 & $47.95 b$ \\
\hline & Mean & 35.93 & 56.04 & 92.78 & & & Mean & $19.80 \mathrm{C}$ & $65.90 \mathrm{~B}$ & $79.33 \mathrm{~A}$ & \\
\hline
\end{tabular}

*The lower cases show the difference between treatments at each harvest time, the capital letters show the difference between harvest times in each treatment. 


\begin{tabular}{|c|c|c|c|c|c|c|c|c|c|}
\hline & \multirow{2}{*}{$\begin{array}{r}\text { MeJA } \\
(\mu \mathrm{M})\end{array}$} & \multicolumn{3}{|c|}{ Shoots } & \multirow[b]{2}{*}{ Mean } & \multicolumn{3}{|c|}{ Roots } & \multirow[b]{2}{*}{ Mean } \\
\hline & & Day 15 & Day 30 & Day 45 & & Day 15 & Day 30 & Day 45 & \\
\hline \multirow{5}{*}{ 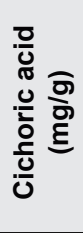 } & 0 & $5.97 \mathrm{Cb}^{*}$ & 13.21 Bc & 18.39 Ad & 12.52 & $7.66 \mathrm{Cc}$ & $13.88 \mathrm{Bd}$ & $28.92 \mathrm{Ac}$ & 16.82 \\
\hline & 10 & $12.48 \mathrm{Cc}$ & $20.41 \mathrm{Bb}$ & $23.60 \mathrm{Ac}$ & 18.83 & $30.10 \mathrm{Cb}$ & $40.15 \mathrm{Bc}$ & $44.51 \mathrm{Ab}$ & 38.25 \\
\hline & 50 & $17.33 \mathrm{Cb}$ & $21.05 \mathrm{Bb}$ & $25.34 \mathrm{Ab}$ & 21.24 & $32.97 \mathrm{Cb}$ & $44.08 \mathrm{Bb}$ & $48.53 \mathrm{Ab}$ & 41.86 \\
\hline & 100 & $18.60 \mathrm{Ca}$ & $31.07 \mathrm{Ba}$ & $35.51 \mathrm{Aa}$ & 28.39 & $40.57 \mathrm{Ca}$ & $49.71 \mathrm{Ba}$ & $54.87 \mathrm{Aa}$ & 48.38 \\
\hline & Mean & 13.59 & 21.43 & 25.71 & & 27.82 & 36.95 & 44.21 & \\
\hline \multirow{5}{*}{ 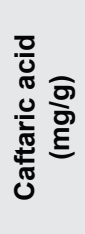 } & 0 & $2.41 \mathrm{Cc}$ & $2.88 \mathrm{Bc}$ & $3.58 \mathrm{Ad}$ & 2.96 & $1.04 \mathrm{Bd}$ & $2.97 \mathrm{Ac}$ & $3.13 \mathrm{Ac}$ & 2.38 \\
\hline & 10 & $3.59 \mathrm{Cb}$ & $4.46 \mathrm{Bb}$ & $5.48 \mathrm{Ac}$ & 4.51 & $3.15 \mathrm{Cc}$ & $6.08 \mathrm{Bb}$ & $7.05 \mathrm{Ab}$ & 5.43 \\
\hline & 50 & $4.43 \mathrm{Ba}$ & $4.49 \mathrm{Bb}$ & $6.16 \mathrm{Ab}$ & 5.03 & $3.83 \mathrm{Cb}$ & $6.45 \mathrm{Bb}$ & $7.33 \mathrm{Ab}$ & 5.87 \\
\hline & 100 & $4.48 \mathrm{Ca}$ & $6.13 \mathrm{Ba}$ & 7.28 Aa & 5.96 & $6.14 \mathrm{Ca}$ & $7.55 \mathrm{Ba}$ & $8.85 \mathrm{Aa}$ & 7.51 \\
\hline & Mean & 3.73 & 4.49 & 5.62 & & 3.54 & 5.76 & 6.59 & \\
\hline \multirow{5}{*}{ 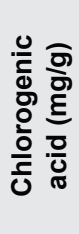 } & 0 & $0.14 \mathrm{Cc}$ & $0.19 \mathrm{Bd}$ & $0.38 \mathrm{Ad}$ & 0.24 & $1.60 \mathrm{Bd}$ & $1.64 \mathrm{Bb}$ & $2.34 \mathrm{Ac}$ & 1.86 \\
\hline & 10 & $0.42 \mathrm{Ca}$ & $0.63 \mathrm{Bb}$ & $0.71 \mathrm{Ab}$ & 0.59 & $2.39 \mathrm{Bc}$ & $2.70 \mathrm{Ab}$ & $2.74 \mathrm{Ab}$ & 2.61 \\
\hline & 50 & $0.47 \mathrm{Ca}$ & $0.72 \mathrm{Ba}$ & $0.87 \mathrm{Aa}$ & 0.68 & $3.06 \mathrm{Bb}$ & 3.19 Ba & $3.49 \mathrm{Aa}$ & 3.25 \\
\hline & 100 & $0.26 \mathrm{Bb}$ & $0.44 \mathrm{Ac}$ & $0.48 \mathrm{Ac}$ & 0.39 & $2.71 \mathrm{Bb}$ & $3.01 \mathrm{Aa}$ & $2.74 \mathrm{Bb}$ & 2.82 \\
\hline & Mean & 0.32 & 0.50 & 0.61 & & 2.44 & 2.64 & 2.83 & \\
\hline \multirow{5}{*}{ 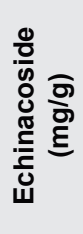 } & 0 & $0.12 \mathrm{Ac}$ & $0.12 \mathrm{Ad}$ & $0.09 \mathrm{Ab}$ & 0.11 & $0.02 \mathrm{Cc}$ & $0.03 \mathrm{Bc}$ & $0.04 \mathrm{Ac}$ & 0.03 \\
\hline & 10 & $0.14 \mathrm{Ab}$ & $0.14 \mathrm{Ac}$ & $0.13 \mathrm{Aa}$ & 0.14 & $0.05 \mathrm{Cb}$ & $0.06 \mathrm{Bb}$ & $0.07 \mathrm{Ab}$ & 0.06 \\
\hline & 50 & $0.19 \mathrm{Ba}$ & $0.25 \mathrm{Aa}$ & $0.11 \mathrm{Cb}$ & 0.18 & $0.05 \mathrm{Bb}$ & $0.07 \mathrm{Aa}$ & $0.07 \mathrm{Ab}$ & 0.06 \\
\hline & 100 & $0.18 \mathrm{Aa}$ & $0.17 \mathrm{Ab}$ & $0.01 \mathrm{Bc}$ & 0.12 & $0.06 \mathrm{Ca}$ & $0.07 \mathrm{Ba}$ & $0.08 \mathrm{Aa}$ & 0.07 \\
\hline & Mean & 0.16 & 0.17 & 0.09 & & 0.04 & 0.06 & 0.06 & \\
\hline \multirow{5}{*}{ 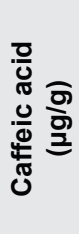 } & 0 & 0.00 & 0.00 & 0.07 & $0.02 \mathrm{~d}$ & $14.20 \mathrm{Bb}$ & $17.32 \mathrm{Ac}$ & $15.52 \mathrm{ABc}$ & 15.68 \\
\hline & 10 & 0.00 & 4.17 & 1.90 & $2.03 \mathrm{c}$ & $14.62 \mathrm{Bb}$ & $22.32 \mathrm{Ab}$ & $20.70 \mathrm{Ab}$ & 19.21 \\
\hline & 50 & 2.13 & 18.00 & 12.10 & $10.74 a$ & $21.31 \mathrm{Ca}$ & $29.90 \mathrm{Aa}$ & $25.53 \mathrm{Ba}$ & 25.58 \\
\hline & 100 & 2.43 & 11.90 & 3.17 & $5.83 b$ & $12.00 \mathrm{Bb}$ & $20.23 \mathrm{Abc}$ & $13.92 \mathrm{Bd}$ & 15.38 \\
\hline & Mean & $1.14 \mathrm{C}$ & $8.52 \mathrm{~A}$ & $4.32 \mathrm{~B}$ & & 15.53 & 22.44 & 18.92 & \\
\hline \multirow{5}{*}{ 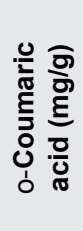 } & 0 & 0.00 & 0.00 & 0.00 & $0.00 \mathrm{c}$ & $0.29 \mathrm{Cd}$ & $0.54 \mathrm{Ad}$ & $0.33 \mathrm{Bb}$ & 0.38 \\
\hline & 10 & 0.08 & 0.25 & 0.10 & $0.14 a$ & $0.55 \mathrm{Bc}$ & $0.62 \mathrm{Ac}$ & $0.35 \mathrm{Cb}$ & 0.51 \\
\hline & 50 & 0.01 & 0.20 & 0.08 & $0.10 \mathrm{~b}$ & $0.61 \mathrm{Bb}$ & $0.78 \mathrm{Ab}$ & $0.55 \mathrm{Ca}$ & 0.65 \\
\hline & 100 & 0.01 & 0.19 & 0.08 & $0.09 \mathrm{~b}$ & $0.77 \mathrm{Ba}$ & $0.84 \mathrm{Aa}$ & $0.59 \mathrm{Ca}$ & 0.73 \\
\hline & Mean & $0.02 \mathrm{C}$ & $0.16 \mathrm{~A}$ & $0.07 \mathrm{~B}$ & & 0.56 & 0.69 & 0.46 & \\
\hline
\end{tabular}

*The lower cases show the difference between treatments at each harvest time, the capital letters show the difference between harvest times in each treatment.

shoots and roots. The highest caffeic acid contents were found in shoots and roots treated with $50 \mu \mathrm{M}$ MeJA and harvested on $30^{\text {th }}$ day as $18.00 \mu \mathrm{g} / \mathrm{g}$ and $29.90 \mu \mathrm{g} / \mathrm{g}$, respectively. Maximum o-coumaric acid in shoots $(0.25 \mathrm{mg} / \mathrm{g})$ was measured from the shoots raised under $10 \mu \mathrm{M}$ MeJA while $100 \mu \mathrm{M}$ MeJA was the most optimum concentration for roots in order to get the maximum o-coumaric acid level $(0.84 \mathrm{mg} / \mathrm{g})$. On the other hand, $30^{\text {th }}$ day was found as an optimum harvest time both shoots and roots for o-coumaric acid. Another interesting result is that all caffeic acid derivatives except echinacoside were found in higher concentrations in roots than shoots. Similarly Bauer ${ }^{10}$ reported that the biochemical constituents of Echinacea roots are often greater than in its shoots.

In this study MeJA was used to enhance the accumulation of CADs in shoots and roots of Echinacea. It is well known that MeJA plays a key role in the plant defence response through altering the gene expression. ${ }^{11}$ MeJA is a signalling and regulatory molecule influencing enzymes of the biosynthetic pathway responsible for secondary metabolite accumulation. ${ }^{12}$ In the present study, MeJA applications significantly increased the CADs. The induction effect of MeJA on phenolic production was in agreement with reported data which revealed that MeJA strongly increased phenolics in 
different plants. ${ }^{13-15}$ According to Chen and Chen ${ }^{16}$, stress signalling molecules increase the synthesis of secondary metabolites by reducing the synthesis of the primer metabolites. These results suggest that the effects of MeJA on secondary metabolite production seem to be due to the activation of related metabolism.

\section{CONCLUSION}

All growth parameters of both shoot and roots decreased in line with the elevating level of MeJA treatments while MeJA treatments increased the CADs in both shoots and roots applied with $100 \mu \mathrm{M}$ MeJA and harvested in 45 days after application. To conclude, MeJA may be promising compound for use in the production of secondary metabolites in Echinacea plants.

\section{ACKNOWLEDGEMENT}

The authors are thankful to TUBITAK (Scientific and Technolog-ical Research Council of Turkey) for the financial support for thisresearch Project (Project number: TOVAG 113O144).

\section{CONFLICT OF INTEREST}

The authors declare No conflict of Interest

\section{ABBREVIATION USED}

CAD: Caffeic Acid Derivative; CADs: Caffeic Acid Derivatives; HPLC: High Performance Liquid Chromatography; MeJA:Methyl Jasmonate; MS: Murashige and Skoog

\section{REFERENCES}

1. Barrett B. Medicinal properties of Echinacea: A critical review. Phytomedicine. 2003;10(1):66-86.

\section{PICTORIAL ABSTRACT}

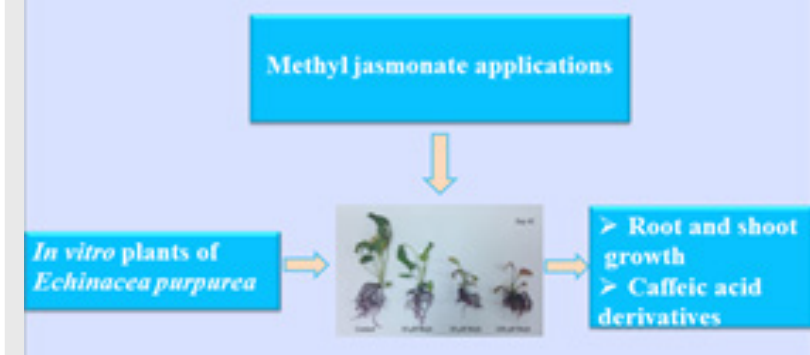

2. Harborne JB, Williams CA. Phytochemistry of the Genus Echinacea. In: S Miller (ed) Echinacea. The Genus Echinacea. CRC Press, Boca Raton, FL. 2004;55-71.

3. Jones AMP, Saxena PK, Murch SJ. Elicitation of secondary metabolism in Echinacea purpurea L. by gibberellic acid and triazoles. Engineering in Life Sciences. 2009;9:205-10.

4. Donnez D, Jeandet P, Clement C, Courot E. Bioproduction of resveratrol and stilbene derivatives by plant cells and microorganisms. Trends Biotechnology. 2009;27:706-13.

5. Beckers, GJM, Spoel, SH. Fine-tuning plant defence signalling: salicylate versus jasmonate. Plant Biology. 2006;8(01);1-10.

6. Liu CZ, Abbasi BH, Gao M, Murch SJ, Saxena PK. Caffeic acid derivatives production by hairy root cultures of Echinacea purpurea. Journal of Agricultural and Food Chemistry 2006;54(22):8456-60.

7. Bulgakov VP, Tchernoded GK, Mischenko NP, Khodakovskaya MV, Glazunov VP, Radchenko SV, et al. Effect of salicylic acid, methyl jasmonate, ethephon and cantharidin on anthraquinone production by Rubia cordifolia callus cultures transformed with the rolB and rolC genes. Journal of Biotechnology. 2002;97(3):213-22.

8. Xiao Y, Gao S, Di P, Chen J, Chen W, Zhang L. Methyl jasmonate dramatically enhances the accumulation of phenolic acids in Salvia miltiorrhiza hairy root cultures. Physiologia Plantarum. 2009;137(1):1-9.

9. Chikezie PC, Ibegbulem CO, Mbagwu FN. Bioactive Principles from Medicinal Plants. Research Journal of Phytochemistry. 2015;9:88-115.

10. Bauer R. Echinacea: Biological effects and active principles. American Chemical Society. 1998;12:140-57.

11. Zid AS, Orihara Y. Polyacetylenes accumulation in Ambrosia maritima hairy root and cell cultures after elicitation with methyl jasmonate. Plant Cell Tissue and Organ Culture. 2005;81(1):65-75.

12. Pauwels L, Morreel K, Witte ED, Lammertyn F, Montagu MV, Boerjan W, et al. Mapping methyl jasmonate-mediated transcriptional reprogramming of metabolism and cell cycle progression in cultured Arabidopsis cells. Proceedings of the National Academy of Sciences of the USA. 2008;5(4):1380-5.

13. Abd El-Mawla AMA, Ibraheim ZZ. Methyl jasmonate induced accumulation of biologically active phenolic compounds in cell cultures of Emex spinosa (L.) Campd. Spatula DD. 2011;1(2):67-71.

14. Jalalpour Z, Shabani L, Afghani L, Sharifi-Tehrani M, Amini SA. Stimulatory effect of methyl jasmonate and squalestatin on phenolic metabolism through induction of LOX activity in cell suspension culture of yew. Journal of Biology. 2014;38(1):76-82.

15. Çetin ES, Baydar GN. Elicitor applications to cell suspension culture for production of phenolic compounds in grapevine. Journal of Agricultural Science. 2016;22(1):42-53.

16. Chen $\mathrm{H}$, Chen F. Effect of yeast elicitor on the secondary metabolism of Ti-transformed Salvia miltiorrhiza cell suspension cultures. Plant Cell Rep. 2000;19(7):710-17.

\section{SUMMARY}

- All growth parameters of both shoot and roots decreased in line with the elevating level of MeJA applications in Echinacea.

- MeJA applications increased the caffeic acid derivatives in both shoots and roots compared to the controls.

- The highest cichoric acid, the main caffeic acid derivative found in Echineceae, was found in shoots and roots applied with $100 \mu \mathrm{M}$ MeJA and harvested in 45 days after application. 


\section{ABOUT AUTHORS}

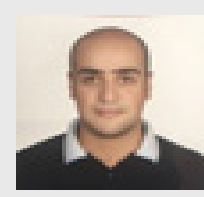

Dr. Tunhan Demirci: He has experience in the area of aromatic and medicinal plants, gene transfer techniques and secondary metabolites. He has published a number of papers in various journals.

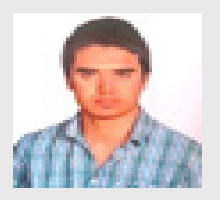

BSc. Serdar Özmen: He is a student for master degree in Agricultural Biotechnology Department of Süleyman Demirel University. He has been working on medicinal plants.

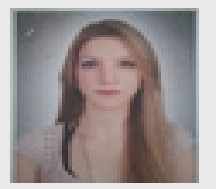

Elif Gökçen Yilmaz: She is a student for Bsc degree in Agricultural Biotechnology Department of Süleyman Demirel University.

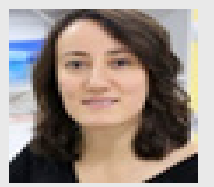

Dr. Özlem Aras Aşci: She is presently working as Dr. in Agricultural Biotechnology Deparment in Süleyman Demirel University. She has experience in tissue culture and secondary metabolites. She has published a number of papers in different journals.

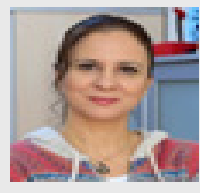

Dr. Nilgün Göktürk Baydar: She is presently working as Professor in Deparment of Agricultural Biotechnology in Süleyman Demirel University. She has experience in stress physiology, plant biotechnology and secondary metabolites. She has got a lot of papers in her expertise area in various journals.

Cite this article: Demirci T, Özmen S, Yilmaz EG, Asci ÖA, Baydar NG. The Influence of Methyl Jasmonate on Growth and Caffeic Acid Derivative Contents of In vitro Shoot and Roots in Echinaceae (Echinacea Purpurea). Indian J of Pharmaceutical Education and Research. 2017;51(3)Suppl:S513-17. 